Pamiętnik Literacki 2018, 1, s. 95-103
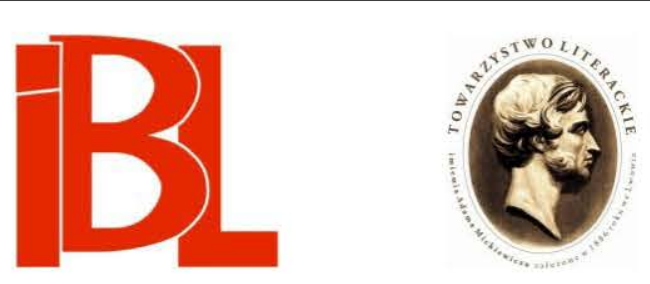

„Biała pani przeszła znów przez salon!...”

Duchy, czarownice i demony w twórczości poetyckiej Marii PawlikowskiejJasnorzewskiej

Jadwiga Jęcz 
Pamiętnik Literacki CIX, 2018, z. 1, PL ISSN 0031-0514

DOI: $10.18318 / \mathrm{pl} .2018 .1 .5$

JADWIGA JECZ Uniwersytet im. Adama Mickiewicza, Poznań

\section{„BIAŁA PANI PRZESZŁA ZNÓW PRZEZ SALON!...” \\ DUCHY, CZAROWNICE I DEMONY W TWÓRCZOŚCI POETYCKIEJ MARII PAWLIKOWSKIEJ-JASNORZEWSKIEJ}

Pewnego razu kilkuletnia Lilka powiedziała do siostry: „w tej szafie siedzi malutka zasuszona czarownica w spiczastym kapelusiku i pogrzebaczem grzebie w stosach starych maminych sukien" ${ }^{1}$, a słowa te były zapowiedzia zainteresowania poetki zjawiskami paranormalnymi. Wybujała fantazja małej dziewczynki, dziecka przesiąkniętego już od momentu narodzin specyficzną atmosferą sztuki i magii, wraz $\mathrm{z}$ upływem lat miała się przekształcić w obsesję powracania do motywów związanych ze światem diabłów, duchów i czarownic. Nie była to jednakże obsesja stała, a przynajmniej wnikliwa analiza wierszy nie upoważnia do postawienia tak zdecydowanej tezy. Wyjątkowa wrażliwość na bodźce zewnętrzne stanowiła źródło nieustannych niepokojów autorki Surowego jedwabiu, które w zależności od jej kondycji psychicznej i komplikacji uczuciowych, a także od ówczesnych wyobrażeń twórczych, malały bądź wzrastały, ujawniając się na kartach poezji.

Inspirowanie się Marii Pawlikowskiej-Jasnorzewskiej czarami, spirytyzmem i okultyzmem faktycznie częściowo były zespolone $z$ jej biografią. Jeszcze w latach wczesnej młodości wraz z siostra pasjami czytywały „zakazane” poradniki traktujące o gusłach, zabobonach i „magicznych” przepisach, spośród których szczególnym zainteresowaniem cieszyła się Hatha Yoga - źródło inspiracji wschodnich dotyczących uprawiania ćwiczeń duchowych. Pozostając pod silnym wpływem lektur, poetka twierdziła, że mijany często na ulicy garbaty Włoch rzuca jej „mal occhio”, wskutek czego zawsze się wówczas potykała. Jedynym antidotum miała być „ręka Fatmy”, talizman przeciw złym urokom, przedstawiający rączkę z dwoma palcami. Kilka lat później w Talizmanach (z tomu Surowy jedwab) Pawlikowska-Jasnorzewska oblecze postać Włocha w kostium poezji i, spoglądając już wówczas z dystansu twórczego, napisze:

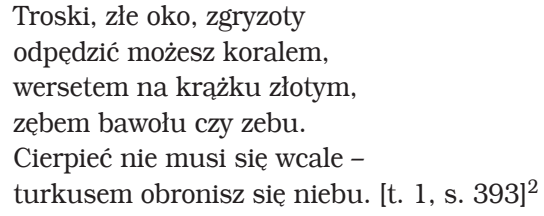

1 M. Sa mozw a ni e c, Maria i Magdalena. Kraków 1956, s. 17.

2 Wszystkie cytowane wiersze pochodzą z wyd.: M. Pawlikow s ka - J a s n or z e w s ka, Poezje ze- 
Mimo przytoczonych przykładów trudno ocenić, w jak wielkim stopniu zainteresowanie Pawlikowskiej-Jasnorzewskiej duchami i czarami wynikało z prostego przełożenia niepokojących treści lektur na życie w świecie rzeczywistym, w jak dużym źródeł należy poszukiwać w wewnętrznych niepokojach wywołanych nieustannym tworzeniem innej rzeczywistości, a przy tym silną potrzebą wiary (bez względu na to, na jakich podstawach miałaby się ona opierać) i wreszcie - jak mocnych dowodów dostarcza liryka, konstruowana przecież z przymrużeniem oka i tendencją do odmalowywania plastycznych obrazów poetyckich, w czym należy doszukiwać się nie zrealizowanego w pełni powołania artystki-malarki. W rodzinie Kossaków nie wyznawano zbyt gorliwie religii katolickiej i młoda poetka mogła próbować zrekompensować sobie owe braki, nie zastanawiając się zbytnio nad dokonywanymi wyborami. Swoisty „miszmasz” magiczno-religijny nie powinien więc budzić zdziwienia, lecz z całą pewnością stanowi temat intrygujący i prowokujący do podjęcia próby omówienia motywów związanych ze światem zjaw, duchów i czarownic w twórczości najwybitniejszej poetki Dwudziestolecia międzywojennego.

Ciekawych wniosków dostarcza analiza tytułów wierszy autorki Śpiacej załogi. Osobliwe zainteresowania unaoczniły się przede wszystkim w tomikach: Różowa magia i Profil białej damy oraz w utworach Rada pani Girard, czarownicy, Biała dama, Straszydło, Rodzina czarownicy i Cień babki. Na drugim biegunie znajdują się wiersze, w których poetka dała wyraz swej obsesji śmierci, a w których, paradoksalnie, nie zawsze poruszony zostaje problem spraw ostatecznych: $O$ kacie październiku (Niebieskie migdały), Skazańcy (Różowa magia), piekło (dancing. karnet balowy), Samobójca (Wachlarz), Zabity w górach (Cisza leśna), Samobójstwo dębu (Śpiaca załoga), Pogrzeb infantki (Paryż), Umarła lalka (Profil białej damy), Śmierć kariatydy (Balet powojów), Epitafium (Krystalizacje) i Do umarłych (Gołąb ofiarny). Dychotomia między często liryczno-nostalgiczną treścią utworów a tytułami ilustruje stan wewnętrznego rozdarcia Pawlikowskiej-Jasnorzewskiej, która $\mathrm{z}$ podobnym uporem malowała subtelne akwarele przedstawiające uwięzionego motyla o kobiecej twarzy i brała udział w seansach spirytystycznych.

W zbiorach $z$ lat 1922-1928 elementy demonologiczno-spirytystyczne w zasadzie nie występują. Do grona tajemniczych istot można zaliczyć jedynie bohaterki $\mathrm{Hi}^{-}$ storii o czarownicach (Niebieskie migdały), które - budząc raczej litość niż przerażenie - na Łysej Górze błagają szatana, aby chociaż on ich nie opuszczał. W innym utworze, Bandyta $i$ diabet $\mathrm{z}$ tomiku Wachlarz, szatan, przypominający bardziej ludowego demona niż emanację sił ciemności, jako jedyny słyszy wołanie skazańca i spełnia jego ostatnie życzenie. Już po raz drugi wizja poetycka autorki nakazuje jej uczynić złego ducha opiekunem opuszczonych. Na tym nie wyczerpuje się jednak przypisywanie szatanowi roli pocieszyciela: w Zamku na lodzie z Różowej magii diabeł, po udzieleniu pomocy, uśmiecha sie „poczciwie - przesmutnie...” (t. 1, s. 97). A bohaterki Historii o czarownicach, zdradzone i wyklęte przez dobro, z własnej woli oddają się pod opiekę zła; zrozpaczone i umęczone, starają się o względy tego, o którym „nigdy nie mówiono, / by [...] rzucił duszę potępiona” (t. 1, s. 33) i opuszczoną. Stwierdzenie to zawarte jest zresztą także w treści Zamku na lodzie

brane. Zebrał i oprac. A. Madyda. Wstęp K. Ćwikliński. Wyd. 3, przejrz. i uzup. T. 1-2. Torun 1997. Cytaty lokalizuję podając w nawiasie numer tomu i stronicy. 
oraz Bandyty i diabła. Do głosu dochodza tutaj jednak nie tyle pierwiastki celowo lagodzące wizerunek księcia ciemności, ile echa przyswojonych treści lektur; figura szatana-pocieszyciela pojawiła się już przecież w Fauście Goethego.

Istoty spoza realnego świata dominującą rolę odegrały w tomikach Paryż i Profil biatej damy z lat 1929-1930. Wpływ magii na poezję Pawlikowskiej-Jasnorzewskiej był wówczas na tyle silny, że charakteryzując tzw. drugi okres twórczości (według typologii Jerzego Kwiatkowskiego ${ }^{3}$ ), obok zaciekawienia autorki natura wymienia się zainteresowanie irracjonalizmem i transcendencją, czarami i wiedźmami, metafizyką, lunatyzmem, somnambulizmem, wróżbami i przesądami. Jednak według Elżbiety Hurnikowej, mimo iż poetka stosuje fachową terminologię, spirytyzm jest przez nią traktowany z przymrużeniem oka, a cień babki ze zbioru Paryż przypomina bezsilnego upiora z utworu Oscara Wilde'a Duch $z$ Kenterwilu ${ }^{4}$. Podobnego zdania był Julian Przyboś, który uważał, że uwielbiane przez Pawlikowską-Jasnorzewską seanse wywoływania duchów dały pretekst tej „radosnej materialistce” do napisania wierszy poświęconych białej damie; wierszy dowcipnych, których mądrość zasadzała się na traktowaniu całej sprawy w sposób niepoważny. Podobne wnioski wysnuł Jan Marx, podkreślając brak pierwiastków demonicznych i czytankowo-bedekerowy charakter utworów o czarownicach z tomu Paryż $\dot{z}^{5}$.

Poemat Paryż z tegoż tomu narodził się w wyobraźni poetki, kiedy opuszczona przez lotnika José Manuela Sarmenta de Beiresa - jedną z największych, jak uważała, miłości jej życia - pisywała smutne listy i wiersze. Pozostając pod wpływem

3 J. Kwiatkowski (wstęp w: M. Pawlikowska-Jasnorzews ka, Wybór poezji. Kraków 1998, s. XXVI-CIII) wyodrębnił trzy okresy twórczości autorki Pocałunków, kolejno wymieniając motywy dominujące wówczas w jej poezji. Typologia zastosowana przez badacza ma charakter porządkujący, niemniej należy uwzględnić stwierdzenie W. Boleckiego (wstęp w: M. Pawlik ow s k a - J a s n or z e w s k a, Być kwiatem?... Wybór wierszy i szkiców poetyckich. Wybór i układ W. B o l e c ki. Warszawa 2000, s. 11): „najważniejsze tematy utworów Pawlikowskiej-Jasnorzewskiej są nie tylko wynikiem ewolucji artystycznej i doświadczeń życiowych poetki, lecz także stałym powracaniem do ich wcześniejszych, jakby zalążkowych opracowań. Miłość nie jest dominującym tematem tylko pierwszego okresu twórczości poetki, natura - drugiego, a śmierć - ostatniego. Wszystkie te i inne tematy istnieją bowiem u Pawlikowskiej w każdym jej tomiku - z różną wszak intensywnością i wyrazistością, wszystkie bowiem są cząstkami tematu znacznie szerszego. Oglądana $z$ takiej perspektywy, Pawlikowska okazuje się bowiem nie tyle poetka tematu miłości, co przede wszystkim - istnienia, w którym miłość jest najbardziej niezwykłym, tajemniczym i ulotnym objawem [...]".

4 E. H u rnik ow a, Maria Pawlikowska-Jasnorzewska. (Zarys monograficzny). Katowice 1999, rozdz. „Magia, chiromancja...”

5 J. Marx (Miłość i śmierć. O poezji Marii Pawlikowskiej-Jasnorzewskiej. Wrocław 2007, rozdz. Jedwabna ezoteryczność i baedekerowy blichtr, s. 205-206) dziwił się, że poetka nie znała XIX-wiecznej książki J. Micheleta, traktującej o średniowiecznych gusłach i czarach. Opisy metod zalecanych przez wiedźmy porażały brutalnością i okrucieństwem. Zdaniem Marxa, dopiero gdyby Pawlikowska-Jasnorzewska zapoznała się ze złowrogą treścią poradników, jej wizja zawarta w Paryżu byłaby naprawdę demoniczna. Według Kw i at k ow s ki e go (op. cit., s. LVI-LVII) stosunek poetki do kwestii wróżbiarsko-spirytystycznej był ambiwalentny. Z jednej strony, otwarte przyznanie się do korzystania z usług paryskich szarlatanów uważać wolno za manifest kobiecej niezależności, a przy tym podporządkowanie rygorom epoki, w której wiara (a może raczej należałoby mówić o modzie) w umiejętność poznawania ukrytych prawd była powszechna. Z drugiej strony jednak Kwiatkowski podkreśla dystans, często zabarwiony szczyptą humoru i ironii, w traktowaniu przez poetkę kwestii magii. 
Charles'a Baudelaire’a, przedstawiła tajemniczą i mroczną stolicę Francji, gdzie „dancing spotyka się z prosektorium, miłość ze śmiercią, flirt z rozpaczą, rozkosz $z$ cierpieniem, przepych salonów $z$ nędzą barłogów, perfumy Diora ze smrodem

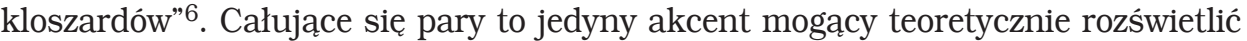
ponura scenerię - a jednak widok zakochanych tylko pogłębia poczucie alienacji. Nawet przystojny Hiszpan (kolejna miłosna nadzieja?) nie zatrzymuje się, nie dostrzegając patrzącej na niego kobiety. Beata Morzyńska-Wrzosek zwróciła uwage na zastosowanie przez poetkę metafor zwierzęcych (wskazujących na głębokie przeżywanie samotności) w celu podkreślenia anonimowości podmiotu w społeczeństwie $^{7}$. Tak więc tłum ludzi jest „brzydki jak mrowisko”, głos gazeciarki „jak ptak zgubiony jęczy”, studenci przypominaja „rój gacków”, a jednostka jest „małą rybką zgubioną wśród rekinów mnóstwa” (t. 1, s. 289-292) ${ }^{8}$. Po zmroku Paryż tchnie duchem śmierci i wciąż unoszącym się w powietrzu trupim odorem nieszczęśników straconych na gilotynie. W Sekwanie nurzaja się zwłoki samobójczyń, sprowokowanych do popełnienia desperackiego czynu rozpaczliwym poczuciem beznadziei, rzeźby zaś chimer z Notre-Dame znienacka zaczynają się poruszać. Połaczenie dwóch żywiołów: kamienia i powietrza, wprowadza dynamizm, a animizacja fragmentów muru bynajmniej nie zachwyca:

\author{
Topielice Sekwany gwiżdża „Hallelujah”, \\ nowy fokstrot, na falach huśtane łagodnie. \\ Na Notre-Dame demony pod niebem waruja \\ i patrzą w dół na Paryż \\ groźnie jak na zbrodnię. \\ Cichym, kamiennym głosem wyją do księżyca, \\ to znów do lamp łukowych, różowych i sinych, \\ zezując w kąt wiadomy, gdzie stoi zazwyczaj \\ Wdowa, paryski upiór, \\ monstrum gilotyny. [t. 1, s. 290-291]
}

Morzyńska-Wrzosek zauważyła również, że punkt obserwacji katedry znajduje się u podstaw budowli, co powoduje uświadomienie sobie jej monumentalności:

Widzenie w nocy uzależnione od elektrycznego oświetlenia nie pozwala ujrzeć zbyt wielu szczegółów strzelistej budowli, jednak podmiot dostrzega kamienne zwierzęta i ożywiając je, wyposaża w nieprzyjazne cechy, a ich odbiór, nie pozbawiony drapieżności, grozy (spoglądają też na gilotynę, publiczne miejsce straceń), ewokuje lęk, przestrach, niepewność, przypomina o intensywnie doznawanej samotności, o silnym uczuciu zagubienia w wielkim mieście. Podobna funkcję w poemacie pełni fragment wprowadzający wieżę Eiffla, bowiem współczesna metalowa konstrukcja, stanowiąc wertykalne centrum krajobrazu, nie sugeruje pozytywnych właściwości, jego charakterystyka nie eksponuje w nim symbolu potęgi technicznej i gospodarczej, a nasuwa raczej myśl o wzbudzającym strach spotkaniu czarownic ${ }^{9}$.

$6 \quad$ Ma rx, op. cit., s. 193.

7 B. Morzyń s ka - Wrzos e k, „...i na piękność, i na wyczyn burzy”. Proces kształtowania tożsamości w poezji Marii Pawlikowskiej-Jasnorzewskiej. Bydgoszcz 2013, s. 154.

$8 \quad$ Nawiasem mówiąc, to ciekawe, iż poetce, tak bardzo kochającej zwierzęta, że dla uratowania myszy nie zawahała się zanurzyć ręki w cuchnącą breję, figury stworzeń posłużyły do zobrazowania przerażającej, osaczającej wręcz atmosfery nocnego miasta.

9 Morzyńska-Wrzosek, op. cit., s. 151. 
Autorka Wachlarza chodziła do najsłynniejszych paryskich wróżek oraz kabalarek i, spoglądając w wody Sekwany, stwarzała świat rusałek i topielic. Zagadkowe paryskie wieszczki w tym były podobne do wszystkich innych wróżek świata, że za usługe żądały tym więcej, im korzystniejsza była wróżba. Jednakże podmiot liryczny Czarowników Paryża w zasadzie nie porusza tej kwestii ${ }^{10}$. Przed oczami odbiorcy ukazuje się cała galeria intrygujacych postaci: fakir Hamam Bej, madame Kahl i „czarownica” Girard, której Pawlikowska-Jasnorzewska poświęciła także osobny utwór. Pod pozorami dobrych rad i życzeń szczęścia, w surrealistycznej scenerii nocnego miasta cielesne upiory osaczaja podmiot liryczny i odsłaniaja skrywane prawdy. Zdecydowanie wybrzmi puenta - wróżbici, żebracy i magowie objawią się jako złowrogie istoty, czatujące na bezbronną ofiarę. Są jak „węże zielone”, „sowy pierzaste”, „senne ropuchy” i „spiczastouche potwory” (t. 1, s. 297), gotowe w każdej chwili zaatakować. Podmiot liryczny, utożsamiany z autorka, przemierza samotnie Paryż w nadziei poznania losów wiarołomnego kochanka, a chciwi oszuści wraz z każdą kolejną otrzymaną monetą zdają się rozmnażać, oplatając ofiarę coraz liczniejszą gromadą. Jedna $z$ wieszczek stawia kabałę, przy czym cennym źródłem informacji okazuje się dla niej twarz rozmówcy; z tego powodu czarownica, wypowiadając po cichu jedno $z$ imion, uważnie śledzi wzrok pytającego. Medium Sarah patrzy w kryształową kulę i od razu ma wgląd w całe życie człowieka, Girard zaś nie tylko poleca klientów opiece pogańskich duchów i demonów, ale także nakazuje przekłuć fotografię dawnego ukochanego. Co istotne, całkiem odmiennie postrzega Pawlikowska-Jasnorzewska złowrogich szarlatanów z Czarowników Paryża, a już zupełnie inaczej podejdzie do kwestii spirytyzmu kilka lat później w Seansie szyb czy w Strachu - o czym będzie mowa w dalszej części pracy. W tym miejscu warto podkreślić różnicę zachodzącą między opisywanymi przez poetkę tzw. czarownicami, w rzeczywistości zaś paryskimi oszustkami, a „autentycznymi” wiedźmami z podań ludowych, ukazanymi w Niebieskich migdałach.

Złowrogo-magiczną atmosferę Paryża odmalowuje Pawlikowska-Jasnorzewska po mistrzowsku, $z$ jednej strony zanurzając się w meandry wyobraźni poetyckiej, Z drugiej natomiast czerpiąc $z$ własnych życiowych doświadczeń. Zwłaszcza spotkanie $z$ Girard dało asumpt do napisania wiersza, w którym znalazło wyraz zainteresowanie poetki magią. Tytułowa czarownica - jedna $z$ wielu paryskich wieszczek - podaje przepis na eliksir miłosny, majacy odmienić serce opornego kochanka. Składniki potrzebne do sporządzenia mikstury (głóg i sowie oczy) wzbudzają wstręt i odrazę, podobnie jak niepokoi nakaz nakłuwania lalki wyobrażającej mężczyznę. Czyżby dochodziły tutaj do głosu wpływy religii Wschodu, doskonale przecież znanej w Dwudziestoleciu międzywojennym?

Przedstawiona w utworze wizja Pawlikowskiej-Jasnorzewskiej stanowi wypadkową doświadczeń poetycko-wróżbiarskich, a postać Girard jest emanacją cech

Żebrak w nagrodę za kilka centimów, daje ci przepowiednię, drukowany świstek, z kwiatem, planeta i wierszem na dzień twych urodzin. Przynosi to rzeczywiste szczéście. [t. 1, s. 296] 
wróżek napotkanych przez autorkę we Francji. Quasi-demoniczna „czarownica” różni się jednak znacząco od wiedźmy z Rodziny czarownicy (Cisza leśna), pozbawionej magicznego ożoga i przysięgającej wierność przyrodzie. Jej monolog, mimo iż poniekąd skierowany do tworów kulturowo przynależących do świata czarnej magii (ropucha, puchacz), ma charakter łagodnej inwokacji - i to inwokacji celowo pozbawionej rozwinięcia. Nie przez przypadek puentę wiersza zastępuje wielokropek, odzwierciedlający nieutuloną tęsknotę podmiotu lirycznego za najbliższymi. Marx dostrzegł paralelę między wierszem Pawlikowskiej-Jasnorzewskiej a Czarownica Kazimiery Iłłakowiczówny, $\mathrm{z}$ upodobaniem powracającej do motywów guseł i czarów obszaru Litwy, gdzie pogaństwo, skryte pod powłoką religii chrześcijańskiej, przetrwało aż do XX wieku ${ }^{11}$. Cisza leśna ukazała się w 1928 roku, czyli już po nieformalnym rozstaniu poetki $z$ Janem Pawlikowskim (oficjalnie małżeństwo zostało unieważnione rok później) i mniej więcej rok po zakończeniu romansu z portugalskim lotnikiem. Dlatego stwierdzenie, że źródeł wyczuwanej w wierszu nostalgii można poszukiwać także w zawirowaniach życiowych autorki Pocałunków, nie powinno nosić znamion nadużycia interpretacyjnego.

Włączony do zbioru Paryż cykl o znaczacym tytule Duchy zawiera cztery wiersze: Straszacy stolarz, Cień babki, Biała dama i Inkub. W Inkubie poetka posługuje się metaforą ludowego demona, udającego namiętnego kochanka i nawiedzającego śpiące kobiety. Lecz jej inkub utożsamiany jest z księżycem. Podmiot liryczny, alter ego autorki, pogrążony w bólu samotności po odejściu ukochanego, nie może liczyć nawet na odwiedziny demona i musi się zadowolić blaskiem księżyca widocznym na poduszce. Nastrój wiersza jest pełen łagodnego smutku; podmiot liryczny tęskni i wciąż wyczekuje powrotu kochanka:

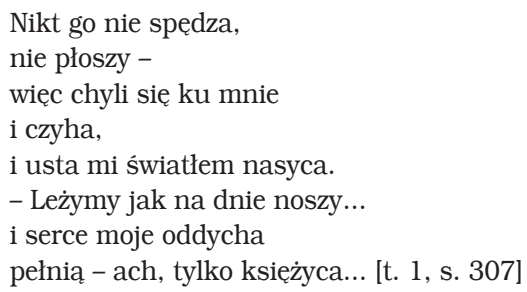

Inny utwór z cyklu, Straszacy stolarz, nawiązuje do poezji Bolesława Leśmiana i jego Szewczyka. W obu wierszach temat dotyczy rzemieślnika pochłoniętego pracą: „obłędnego szewczyka” i stolarza „obłąkanego robota” (t. 1, s. 304). Na tym podobieństwo się nie kończy, gdyż zarówno u Pawlikowskiej-Jasnorzewskiej, jak i u Leśmiana akcja rozgrywa się w nocy. Atmosfera panująca w Straszacym stolarzu jest gęsta od niepokoju: grozę wzbudza jednak nie tyle sam tytuł czy tematyka śmierci, ile jej skonfrontowanie $z$ motywem ożywienia narzędzi i zastosowanie określeń obrazujących stan smutku. W pierwszej strofie czytamy:

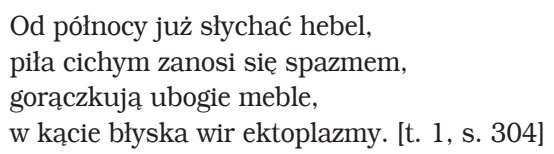


Autorka Ciszy leśnej kilkakrotnie wprowadzała termin „ektoplazma” w „upiornych” Etiudach wiosennych z Utworów rozproszonych („Za chmura ektoplazmy, którą wiosna dymi”, t. 2, s. 223) ${ }^{12}$ czy w Białej damie z Profilu białej damy (widmo ma „suknię z ektoplazmy” i „szal nie perski, lecz ektoplazmiczny”, t. 1, s. 323-324). Szczegółom stroju zjawy poświęciła Pawlikowska-Jasnorzewska wiele uwagi, dając tym samym wyraz nie tylko staranności poetki-erudytki, ale również zainteresowaniu modą. Białą damę ubrała w astralną krynolinę i bieliznę $z$ haftów odycznych oraz mitenki, co świadczy o tym, że zjawa nie przypomina typowego ducha - ma bardzo ludzkie dłonie. Na charakterystykę widma składają się też elementy ściśle związane $z$ tematyka śmierci. Dla podmiotu lirycznego biała dama jest coraz b a rdzi j j ni ż̇y a, jest cmentarną madonną doświadczająca „trumiennej tremy” (t. 1, s. 323). Podmiot liryczny dostrzega tęsknotę damy za miłością, z czym się zresztą utożsamia, przeciwstawiając nauce irracjonalny świat uczuć.

Każda część garderoby zjawy została stworzona z substancji nienamacalnych bądź z cienkiej, ledwo dostrzegalnej pajęczyny. Ten sam motyw pojawił się już w utworze Cień babki, gdzie widmo nosi tiurniurę z pajęczyn i okrywa się indyjskimi muślinami z pyłu. Próba ustalenia statusu ontologicznego tytułowej babki nakazuje dopatrzyć się w jej postaci cech cienia (pozostałości) cienia (synonimu zjawy) - niejako podwójnej śmierci czy może raczej, parafrazując Norwida, stanu podwójnego bez-istnienia. W twórczości autorki Pocałunków każda fotografia jest traktowana jak widmo lub cień utraconego kochanka. Babka jest „cieniem swych fotografij” (t. 1, s. 305), ale jej dwukrotna śmierć, mimo silnie nacechowanego semantycznie tytułu, nie wzbudza strachu, lecz żal.

Kolejny wiersz z cyklu Duchy, Biała dama, rozpoczyna się mocnym akcentem:

\author{
„Biała pani przeszła znów przez salon!” \\ - szepcze służba w kredensie ze zgrozą. - \\ „Znak, że nowe nieszczęścia się zwalą! \\ W całym domu czuć już tuberozą". [t. 1, s. 306]
}

Biała zjawa, wydzielając woń tuberozy, snuje się po domu pogrążonym w ciem-

Etiudy wiosenne to zbiór zawierający 10, opatrzonych datami, miniatur, w których podmiot liryczny, z uwagą obserwując krajobraz, opisuje zmiany zachodzące w przyrodzie. Mimo pozornie pogodnej atmosfery panującej w wierszach pojawiaja się w każdej z miniatur akcenty związane ze śmiercią i zniszczeniem. Np. zestawienie w tym samym fragmencie „uśmiechniętych ust [...] wiatru kwietniowego” z opisem koszuli - postrzeganej przez podmiot liryczny jako wisząca „akrobatka [...] bez głowy" (t. 2, s. 224) - wywołuje nagły zgrzyt i budzi bliżej nie określoną grozę. W innej miniaturze (21 marzec) czytamy:

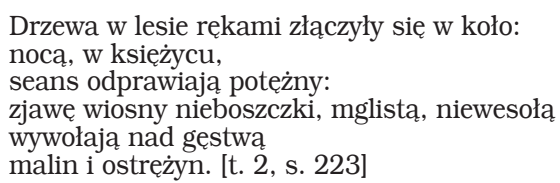

Przytoczony fragment zasługuje, w kontekście tematu pracy, na szczególną uwagę: z jednej strony, metaforyczne posłużenie się nomenklaturą spirytystyczną przypomina po raz kolejny o fascynacjach poetki, z drugiej natomiast odzwierciedla jej wewnętrzne niepokoje - często, nawet w momentach zachwytu nad pięknem przyrody, nie potrafiła się ona uwolnić od złych przeczuć i myśli o sprawach ostatecznych. 
nościach. Nie bez powodu poetka wybrała akurat ten kwiat: zapach tuberozy jest bardzo intensywny, ale co najważniejsze - najsilniej czuje się go wieczorem i w nocy, porze uwielbianej przez duchy i widma. Ukazanie się zjawy niepokoi służących. Nie obawiają się oni jednak jej pozaziemskiego wyglądu, podobnie jak nie przeraża ich świadomość, że biała dama jest widmem. Paradoksalnie, ich strach ma podstawy racjonalne; poprzednie wizyty zjawy były zwiastunem nieszczęść, dlatego lęk rodzi się z bezradności i konieczności całkowitego zdania się na los. W zwrotce drugiej, zdecydowanie opozycyjnej w stosunku do pierwszej, postaciom przerażonych służacych przeciwstawiono zakochanego $\mathrm{w}$ damie młodzieńca. Niespodziewanie, $\mathrm{z}$ bezcielesnej postaci rodzi się ciało, które można objąć i obdarzyć miłosnym uściskiem.

Podobny zabieg zwyciężenia grozy przez miłość zastosowała Pawlikowska-Jasnorzewska w Strachu (pierwotny tytuł: Zjawa) z Profilu białej damy i w Nieudanym seansie (pierwotny tytuł: Miłość na seansie) z tego samego zbioru. W pierwszym utworze widmo dziewczyny, świadome własnej szpetoty, cierpi z powodu niezaspokojonego uczucia. Jednak ta postać stanowi wyłącznie pretekst do podjęcia refleksji nad rozdźwiękiem panującym między ułudą a rzeczywistością. Dla niedostępnego kochanka dziewczyna jest zmora, dla niej samej - początkowo złotowłosa pięknością. Dopiero w finale definiuje siebie jako non sens, paradoksalnie wychodząc naprzeciw opinii ukochanego. Wyeksponowany w wierszu wątek ulotności odzwierciedla wygłaszaną wielokrotnie opinię poetki dotycząca niestałego charakteru uczucia miłosnego.

Pawlikowska-Jasnorzewska sugeruje, że istoty spoza realnego świata nie tylko są bardziej intrygujące od ludzi, lecz także mówią o rzeczach o wiele ważniejszych. Zdecydowanie mocniej wybrzmi ten pogląd w Materializacji (Profil białej damy) podejmując grę $z$ mitem, podmiot liryczny wyraża żal, że Faustyn nie zadowolił się towarzystwem widma i za wszelką cenę dążył do uzyskania namacalnego kształtu. Znamienny jest fragment:

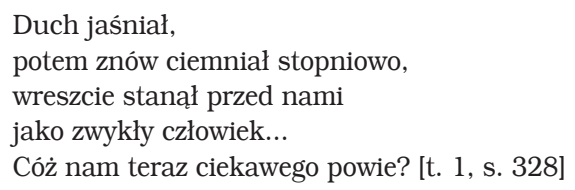

Natomiast w Nieudanym seansie, w czasie wywoływania duchów, pomiędzy siedzącymi bardzo blisko siebie uczestnikami rodzi się miłosne uczucie. Magdalena Samozwaniec pisała zresztą, że rytualne wywoływanie duchów miało częściej charakter erotyczny niż magiczny - w Dwudziestoleciu międzywojennym seanse stanowiły jedną $z$ niewielu okazji, aby móc się dotykać, nie narażając się na utratę reputacji i złośliwe komentarze. Dziewczyna i chłopak z Nieudanego seansu już nie słuchają przesłania z zaświatów; magiczny fluid ulotnił się, stolik znieruchomiał i:

\section{$Z$ białej ręki w dłoń męską przeniknęło drżenie i przyszła miłość zamiast duchów. [t. 1, s. 325]}

Nietypowy przebieg ma również metaforyczna sesja spirytystyczna $z$ wiersza Seans szyb (Profil białej damy), w czasie którego uczestnicy: noc, księżyc i mróz, wywołują zjawy - zmaterializowane na szybach rośliny - i dowiadują się, że jedynym pragnieniem duchów jest prawdziwe życie. Pawlikowska-Jasnorzewska powraca tu 
do motywu tęsknoty za pełnią egzystencji, która, jak w Umarłej lalce, stanowi przedmiot refleksji nie tylko ludzkiej.

Szczególnym typem istoty fantastycznej jest Komandor (Kamienny Gość) z wiersza Don Juan i doña Anna. Wspomniany zaledwie w ostatnim wersie „EL CONVIVADOR DE PIEDRA”, ożywiony posag nagrobny, który w opowieści o don Juanie przybywał, aby po raz ostatni wezwać uwodziciela do nawrócenia, jest postacią z pogranicza dwóch światów: ziemskiego, symbolizowanego przez kamienną figurę, i pozaziemskiego - reprezentowanego przez duszę (może raczej: tchnienie Boga), siłę sprawcza ożywiającą kamień. W utworze Pawlikowskiej-Jasnorzewskiej, pisanym tuż przed oficjalnym rozstaniem $z$ drugim mężem, podmiot liryczny przestrzega: „Doñy Anny porzucać nie wolno” (t. 1, s. 301). Z zemsty za krzywdę wyrządzoną Annie (a pośrednio także innym oszukanym kobietom) Kamienny Gość wciagnie don Juana do piekła; tym razem, w przeciwieństwie do pozostałych wiarołomnych mężczyzn z poezji autorki Pocałunków, kochanek poniesie zasłużoną karę. A Komandor niespodziewanie stanie się najbardziej złowrogim widmem z całego kanonu pozaziemskich istot portretowanych przez Pawlikowska-Jasnorzewską na kartach poezji.

Analiza obecności duchów, demonów i czarownic znacząco poszerza pole interpretacji twórczości Pawlikowskiej-Jasnorzewskiej. Pierwiastki świata nieracjonalnego wzbogacają subtelną tkankę języka poezji i stanowią świadectwo erudycji oraz wrażliwości na słowo. Przede wszystkim jednak dowodzą emocjonalnego rozdarcia autorki najpiękniejszych wierszy Dwudziestolecia, grającej na fortepianie fragmenty Szeherezady, a w ogrodzie wzywającej imienia szatana; poetki nieustannie popadającej w skrajne stany emocjonalne, przez całe życie poszukującej ideału miłości i nieustannie tę miłość niszczącej; kobiety-sylfidy, zachwycającej się pięknem przyrody, a przy tym pograżonej w lekturze poradników czarnej magii i przepisów na czarodziejskie eliksiry. Czarownice, diabły, demony, jak też szarlatani, magowie i fakirzy niespodziewanie stają się jednymi z ważniejszych symboli psychicznego rozdarcia pomiędzy potrzebą miłości a dążeniem do poznania ukrytych prawd.

Abstract

JADWIGA JĘCZ Adam Mickiewicz University, Poznań

\section{"WHITE LADY PASSED THE SALON AGAIN!..." GHOSTS, WITCHES AND DEMONS}

IN MARIA PAWLIKOWSKA-JASNORZEWSKA'S POETRY

The article aims at discussing the motive of extra-terrestrial creature presence (devils, witches, ghosts) in the poems by the most outstanding poetess of the inter-war period. Maria Pawlikowska-Jasnorzewska showed her interest in magic and seances as early as in her childhood, which was attested primarily in her 1929-1930 collections of poems: Paryż (Paris) (especially the cycle Duchy 〈Ghosts〉) and Profil białej damy (A Profile of White Lady). The paper points at some elements which prove the poetess' fascination, namely titles of collections and single poems (Różowa magia 〈Pink Magic〉, Rada pani Girard, czarownicy (The Advice of Mme, Girard, a Witch〉), poems that reflect experience of a forlorn poetess (Czarownicy Paryża 〈The Magicians of Paris〉) or such poems which mirror her acquaintance with books that touch demonological problems (Historia o czarownicach 〈A Tale of Three Witches〉), and ultimatelypoems which bring the problem of gentle spiritism and spinning around the theme of necessity of love (Nieudany Seans (An Unsuccessful Seance〉). Ghosts, demons and witches in Pawlikowska-Jasnorzewska's take various shapes each of which, as the author of the paper maintains, deserves better recognition. 